What is the relationship between morals and politics?

Oliver Scott Curry

oliver.curry@anthro.ox.ac.uk

www.oliverscottcurry.com

11 March 2020

\begin{abstract}
What's the relationship between morals and politics? According to Moral Foundations Theory (MFT), people rely on multiple evolved intuitive "foundations" when making moral decisions, including: Care, Fairness, Loyalty, Authority, and Purity. A substantial body of previous research has found that, when making moral decisions, political liberals place more emphasis on Care and Fairness, whereas political conservatives place more emphasis on Loyalty, Authority, and Purity. However: the way that this research has conceptualised moral and politics has been criticised; there have been some anomalous and contradictory empirical findings; and it remains unclear whether the relationship between morals and politics is causal as opposed to merely correlational. Here I review the literature and make suggestions for future research.
\end{abstract}

This working paper was a contribution to a JRC/EC project on "Science of values and identity in the political process". 


\section{What is the relationship between morals and politics?}

Oliver Scott Curry

oliver.curry@anthro.ox.ac.uk

www.oliverscottcurry.com

11 March 2020

\section{Introduction}

What is morality? What is politics? And how are the two related? Recent research suggests that morality is a collection of instincts, intuitions, inventions and institutions designed to promote cooperative social relations (Curry, 2016; Greene, 2015:40; Haidt \& Kesebir, 2010:800; Rai \& Fiske, 2011:59; Sterelny \& Fraser, 2016:1; Tomasello \& Vaish, 2013:231). There are many types of cooperation, and so this view suggests that there will be many different types of morality. Politics, meanwhile, can be seen as coalitional conflict over which types of cooperation to promote, what cooperative schemes and collective goods governments should pursue, and how the benefits generated by this cooperation should be distributed (Petersen, Sznycer, Sell, Cosmides, \& Tooby, 2013). These conflicts are typically won by the larger, more powerful coalition (Pietraszewski, Curry, Petersen, Cosmides, \& Tooby, 2015; Riker, 1962).

Together, these theories predict that there should be a relationship between a person's morals and politics, because both reflect underlying preferences for cooperation. Individuals who benefit from a particular type of cooperation will endorse the corresponding moral values, and support policies that promote that form of cooperation (Weeden \& Kurzban, 2015). For example, someone who benefits from a supportive kin network is likely to endorse morals relating to family values, and to support political parties that promote family-friendly policies. To the extent that individuals benefit from different types of cooperative social arrangements, they will be likely to hold different moral and political views. And individuals with different portfolios of cooperative preferences may form different political parties to pursue their common interests. As we shall see, recent empirical research has indeed found evidence of such a relationship between morals and politics.

\section{Moral Foundations}

To date, most empirical research investigating the link between morals and politics has been conducted within the framework provided by Moral Foundations Theory (MFT; Haidt \& Joseph, 2004).

MFT argues that "Moral systems are interlocking sets of values, virtues, norms, practices, identities, institutions, technologies, and evolved psychological mechanisms that work together to suppress or regulate selfishness and make cooperative social life possible" 
(Haidt \& Kesebir, 2010). What's more, MFT argues that, because humans face multiple social problems, they have multiple moral values. They rely on multiple 'foundations' when making moral decisions. These foundations include: Care, Fairness, Loyalty, Authority, and Purity. Care is concerned with "the suffering of others, including virtues of caring and compassion". Fairness is concerned with "unfair treatment, cheating, and more abstract notions of justice and rights". Loyalty is concerned with the "obligations of group membership, such as loyalty, self-sacrifice, and vigilance against betrayal". Authority is concerned with "social order and the obligations of hierarchical relationships, such as obedience, respect, and the fulfillment of role-based duties". And Purity is concerned with "physical and spiritual contagion, including virtues of chastity, wholesomeness, and control of desires" (Haidt \& Kesebir, 2010). These Moral Foundations have been operationalised, and measured, by the Moral Foundations Questionnaire (MFQ; Graham et al., 2011).

\section{Liberals and Conservatives}

Early work using the MFQ found that liberals tend to place greater emphasis on the moral foundations of Care and fFairness, whereas conservatives place greater emphasis on the moral foundations of Loyalty, Authority and Purity (see Figure 1, from: Graham, Haidt, \& Nosek, 2009). (See also: Graham, Nosek, \& Haidt, 2012; Koleva, Graham, lyer, Ditto, \& Haidt, 2012). Indeed, one of the original motivations behind the development of MFT was to demonstrate that American liberals did not have a monopoly on morality, that there was more to morality than care and fairness, and that some of the concerns of conservatives could properly be described as moral too.

Subsequent research has provided considerable evidence for this pattern. A large on-line sample using the MFQ found the same pattern of liberal-conservative differences around the world (Graham et al., 2011). The pattern has also been partially or fully replicated by independent research teams in France (Metayer \& Pahlavan, 2014), Sweden (Nilsson \& Erlandsson, 2015), Italy (Milesi, 2017), Turkey (Yalcindag et al., 2019; Yilmaz \& Saribay, 2019; Yilmaz, Saribay, Bahcekapili, \& Harma, 2016), Finland (Kivikangas, Lonnqvist, \& Ravaja, 2017), Russia (Sychev, Belousov, \& Protasova, 2019) and Taiwan (Hsu, Huang, \& Hwang, 2019).

Research has also found that endorsement of the liberal and conservative foundations correlate with: responses to questions about hot button culture-war issues such as abortion, teaching creationism same-sex marriage, gun control, terrorism, flag burning, immigration, stem cell research (Koleva et al., 2012) and especially traditional sexual morality (Malka et al., 2016); support for 'cooperative' and 'militant' internationalist foreign policy views (Kertzer, Powers, Rathbun, \& Iyer, 2014); and willingness to participate in civic organisations promoting left-wing (gender equity and water rights) and right-wing (religious and business) causes (Milesi \& Alberici, 2018). Endorsement of liberal 
Figure 1: The relationship between

political identity and five moral

foundations

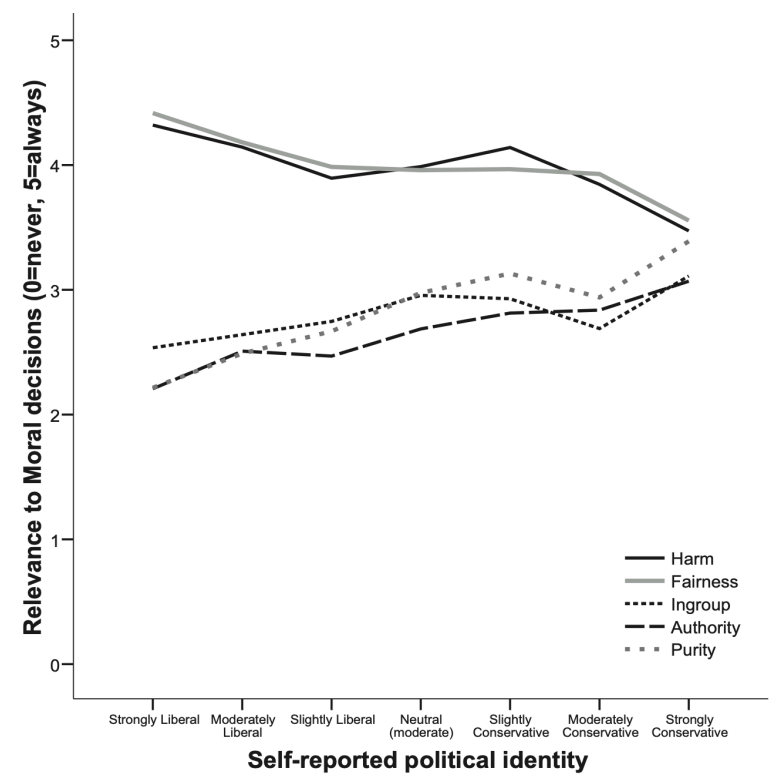

foundations (especially Fairness) and conservative foundations (especially Purity) also correlated with support for Barack Obama and Mitt Romney respectively in the 2012 US Presidential election (Franks \& Scherr, 2015). And a combined measure of the conservative foundations of Authority and Purity correlated with support for Donald Trump in the 2016 election (Weinschenk \& Dawes, 2019).

Aside from survey research, thematic analysis of open-ended justifications offered for party affiliation showed that Democrats referred more to liberal moral foundations, and Republicans referred more to conservative moral foundations (Rempala, Okdie, \& Garvey, 2016). Similarly, analysis of open-ended discussion of vote preferences from the 2012 American National Election Study found that: "Liberals are more likely to mention considerations related to care and fairness, whereas conservatives are more likely to emphasize the moral foundation of loyalty" (Kraft, 2018). A similar pattern, with some exceptions, has been observed in analyses of tweets from the US public and politicians (except for harm, loyalty, and purity; Sterling \& Jost, 2018); and political extremists (except for loyalty; Alizadeh, Weber, Cioffi-Revilla, Fortunato, \& Macy, 2019). (But see: Neiman, Gonzalez, Wilkinson, Smith, \& Hibbing, 2016).

Finally, experiments have found that framing political policies with liberal or conservative moral foundations entrenched support among their respective bases (Day, Fiske, Downing, \& Trail, 2014; see also: Miles, 2016). And framing liberal economic policies with conservative moral values ("like patriotism, family, and respect for tradition-as opposed to more liberal value concerns like equality and social justice") increased support among 
conservatives (and moderates) without decreasing support from liberals (Voelkel \& Willer, 2019).

These findings chime with previous research that has identified a fundamental distinction between "contractual" and "communal" values (Schwartz, 1992), or with David Goodhart's distinction between the 'anywheres' and the 'somewheres' (Goodhart, 2017). (See also: Inglehart \& Baker, 2000). And they are consistent with the notion that underlying differences in social preferences are expressed in moral and political ways. Specifically, liberals appear more individualist and impartial, benefitting more from (and hence placing a greater value on) novel relationships, whereas conservatives appear more communityminded and partial, benefitting more from (and hence placing a greater value on) established familial, communal and hierarchical relationships. Or to put it another way: liberals seek new relationships, conservatives defend the ones they already have.

\section{The loyal opposition}

However, this body of work has its limits, and has been criticised.

First, it has been argued that MFT omits some important moral values (such as special obligations to kin, heroism, and property rights), and conflates others (such as reciprocity and fairness) (Curry, 2019; Curry, Jones Chesters, \& Van Lissa, 2019). And some research has questioned whether Purity constitutes a distinct moral domain (Gray, Schein, \& Ward, 2014).

Second, MFT's five-factor model of morality has not been well supported by studies using the MFQ (Curry, 2019; Curry et al., 2019). Despite promising five moral foundations, the MFQ typically delivers only two - a combined Care-Fairness foundation, and a combined Loyalty-Authority-Purity foundation - and it is these two dimensions that are usually used in research on moral and political psychology. And so, rather than revealing how political ideology varies on five dimensions, this research shows how it varies on two - the two that were originally designed to capture liberal and conservative concerns.

Third, it has been argued that the operationalisation and measurement of the moral foundations has introduced confounds, such that some results may be exaggerated or an artefact of the questionnaire wording. For example, conservatives may endorse respect for authority not because of any general tendency to be more authoritarian, but because participants in surveys tend to implicitly assume that the authorities referred to are conservative (and would give a different answer if asked about liberal authorities). This effect can also be caused by the explicit content of the items. Questions about the relevance and import of 'loyalty to one's country' are likely to elicit different responses from questions about 'loyalty to one's labor union' (Voelkel \& Brandt, 2019). (See also: S 
Clifford, 2017). And, sure enough, in studies where these artefacts are removed, the differences between liberals' and conservatives' moral values decrease (but do not dissappear; Scott Clifford, lyengar, Cabeza, \& Sinnott-Armstrong, 2015; Voelkel \& Brandt, 2019). Similarly, Purity items that refer to 'acting in a way that God would approve of' elicit different responses in liberal and conservative religious congregations; the relationship between conservatism and Authority and Purity was weaker in liberal religious black students (Davis et al., 2016).

Fourth, there is evidence of liberals and conservatives relying on the same foundations in some instances. For example, liberals cite fairness and rights in support of same-sex, whereas conservative cite purity to defend traditional marriage. And conservatives cite fairness and rights in support of economic development (the Keystone XL oil pipeline), whereas liberals cite purity to defend the environment (Frimer, Tell, \& Motyl, 2017). Liberals and conservatives also seem to rely on the same moral foundations (care, fairness, and purity, but not authority or loyalty) when evaluating influential people as moral exemplars (Frimer, Biesanz, Walker, \& MacKinlay, 2013). And a recent large meta-analysis of liberal and conservative texts has not replicated previous findings: compared to liberals, conservatives used slightly more authority and purity words, but fewer loyalty words, and the same number of care and fairness words (Frimer, 2020)

Fifth, it has been argued that political ideology does not vary along a single dimension (such as liberal-conservative, or left-right), and that the use of more complicated measures, that capture for example, the distinct dimensions of social and economic conservatism (Everett, 2013), can and do yield more complicated patterns of results (Haidt, Graham, \& Joseph, 2009; Weber \& Federico, 2013). (For an attempt to insert libertarianism into moral foundations, see: Iyer, Koleva, Graham, Ditto, \& Haidt, 2012).

Finally, it is unclear whether the relationship between morals and politics is causal, as opposed to correlational, or whether both are caused by a third variable. For example, cross-lagged correlations of survey data suggest that Morality at Time 1 does not predict Politics measured at Time 2 (but Politics measured at Time 1 does predict Morals at Time 2) (Hatemi, Crabtree, \& Smith, 2019). The authors of this study conclude provocatively: "Moral Foundations do not cause or meaningfully predict political ideology. Political orientations are more stable across time than Moral Foundations, and Moral Foundations are more likely a product of political orientations rather than the reverse" (Hatemi et al., 2019). On this view, instead of prior moral values determining the political groups you join, the groups you join determine the moral values you hold. 


\section{Conclusion}

There does seem to be a relationship between morality and politics; and this relationship is consistent with the view that morals and politics reflect underlying preferences for pattens of cooperative social relationships. However, the precise nature of the relationship remains unclear, and it remains to be seen whether more sophisticated theories and measures, and more explicit tests of variables that might explain them both, can yield a more penetrating analysis, and a more unified theory, of morality and politics. 


\section{Bibliography}

Alizadeh, M., Weber, I., Cioffi-Revilla, C., Fortunato, S., \& Macy, M. (2019). Psychology and morality of political extremists: evidence from Twitter language analysis of altright and Antifa. Epj Data Science, 8. doi:10.1140/epjds/s13688-019-0193-9

Clifford, S. (2017). Individual Differences in Group Loyalty Predict Partisan Strength. Political Behavior, 39(3), 531-552. doi:10.1007/s11109-016-9367-3

Clifford, S., lyengar, V., Cabeza, R., \& Sinnott-Armstrong, W. (2015). Moral foundations vignettes: a standardized stimulus database of scenarios based on moral foundations theory. Behavior Research Methods, 47(4), 1178-1198. doi:10.3758/ s13428-014-0551-2

Curry, O. S. (2016). Morality as Cooperation: A Problem-Centred Approach. In T. K. Shackelford \& R. D. Hansen (Eds.), The Evolution of Morality (pp. 27-51): Springer International Publishing.

Curry, O. S. (2019, March 26). What's Wrong with Moral Foundations Theory, and How to get Moral Psychology Right. Behavioral Scientist. Retrieved from https:// behavioralscientist.org/whats-wrong-with-moral-foundations-theory-and-how-to-getmoral-psychology-right/

Curry, O. S., Jones Chesters, M., \& Van Lissa, C. J. (2019). Mapping morality with a compass: Testing the theory of 'morality-as-cooperation' with a new questionnaire. Journal of Research in Personality, 78, 106-124. doi:https://doi.org/10.1016/ j.jrp.2018.10.008

Davis, D. E., Rice, K., Van Tongeren, D. R., Hook, J. N., DeBlaere, C., Worthington, E. L., \& Choe, E. (2016). The Moral Foundations Hypothesis Does Not Replicate Well in Black Samples. Journal of Personality and Social Psychology, 110(4), E23-E30. doi:10.1037/pspp0000056

Day, M. V., Fiske, S. T., Downing, E. L., \& Trail, T. E. (2014). Shifting Liberal and Conservative Attitudes Using Moral Foundations Theory. Personality and Social Psychology Bulletin, 40(12), 1559-1573. doi:10.1177/0146167214551152

Everett, J. A. C. (2013). The 12 Item Social and Economic Conservatism Scale (SECS). PLOS ONE, 8(12), e82131. doi:10.1371/journal.pone.0082131

Franks, A. S., \& Scherr, K. C. (2015). Using Moral Foundations to Predict Voting Behavior: Regression Models from the 2012 US Presidential Election. Analyses of Social Issues and Public Policy, 15(1), 213-232. doi:10.1111/asap.12074

Frimer, J. A. (2020). Do liberals and conservatives use different moral languages? Two replications and six extensions of Graham, Haidt, and Nosek's (2009) moral text analysis. Journal of Research in Personality, 84, 103906. doi:https://doi.org/10.1016/ j.jrp.2019.103906

Frimer, J. A., Biesanz, J. C., Walker, L. J., \& MacKinlay, C. W. (2013). Liberals and conservatives rely on common moral foundations when making moral judgments about influential people. Journal of Personality and Social Psychology, 104(6), 1040-1059. doi:10.1037/a0032277

Frimer, J. A., Tell, C. E., \& Motyl, M. (2017). Sacralizing Liberals and Fair-Minded Conservatives: Ideological Symmetry in the Moral Motives in the Culture War. Analyses of Social Issues and Public Policy, 17(1), 33-59. doi:10.1111/asap.12127

Goodhart, D. (2017). The Road to Somewhere: The Populist Revolt and the Future of Politics: C. Hurst \& Co.

Graham, J., Haidt, J., \& Nosek, B. A. (2009). Liberals and Conservatives Rely on Different Sets of Moral Foundations. Journal of Personality and Social Psychology, 96(5), 1029-1046. doi:10.1037/a0015141

Graham, J., Nosek, B. A., \& Haidt, J. (2012). The Moral Stereotypes of Liberals and Conservatives: Exaggeration of Differences across the Political Spectrum. PLoS ONE, 7(12). doi:10.1371/journal.pone.0050092 
Graham, J., Nosek, B. A., Haidt, J., lyer, R., Koleva, S., \& Ditto, P. H. (2011). Mapping the Moral Domain. Journal of Personality and Social Psychology, 101(2), 366-385. doi:Doi 10.1037/A0021847

Gray, K., Schein, C., \& Ward, A. F. (2014). The myth of harmless wrongs in moral cognition: Automatic dyadic completion from sin to suffering. Journal of Experimental Psychology: General, 143(4), 1600-1615. doi:http://dx.doi.org/10.1037/a0036149

Greene, J. D. (2015). The rise of moral cognition. Cognition, 135(0), 39-42. doi:http:// dx.doi.org/10.1016/j.cognition.2014.11.018

Haidt, J., Graham, J., \& Joseph, C. (2009). Above and Below Left-Right: Ideological Narratives and Moral Foundations. Psychological Inquiry, 20(2-3), 110-119. doi:Pii $91373727710.1080 / 10478400903028573$

Haidt, J., \& Joseph, C. (2004). Intuitive ethics: how innately prepared intuitions generate culturally variable virtues. Daedalus, 133(4), 55-66. Retrieved from https:// www.mitpressjournals.org/doi/abs/10.1162/0011526042365555

Haidt, J., \& Kesebir, S. (2010). Morality. In S. Fiske, G. Gilbert, \& G. Lindzey (Eds.), Handbook of Social Psychology (5th ed., pp. 797-832). Hoboken, NJ: Wiley.

Hatemi, P. K., Crabtree, C., \& Smith, K. B. (2019). Ideology Justifies Morality: Political Beliefs Predict Moral Foundations. American Journal of Political Science, 63(4), 788-806. doi:10.1111/ajps.12448

Hsu, H. Y., Huang, L. L., \& Hwang, K. K. (2019). Liberal-conservative dimension of moral concerns underlying political faction formation in Taiwan. Asian journal of social psychology, 22(3), 301-315. doi:10.1111/ajsp.12367

Inglehart, R., \& Baker, W. E. (2000). Modernization, cultural change, and the persistence of traditional values. American Sociological Review, 65(1), 19-51. doi:Doi $10.2307 / 2657288$

lyer, R., Koleva, S., Graham, J., Ditto, P., \& Haidt, J. (2012). Understanding Libertarian Morality: The Psychological Dispositions of Self-Identified Libertarians. PLoS ONE, 7(8), e42366. doi:10.1371/journal.pone.0042366

Kertzer, J. D., Powers, K. E., Rathbun, B. C., \& lyer, R. (2014). Moral Support: How Moral Values Shape Foreign Policy Attitudes. The Journal of Politics, 76(3), 825-840. doi:10.1017/s0022381614000073

Kivikangas, J. M., Lonnqvist, J. E., \& Ravaja, N. (2017). Relationship of Moral Foundations to Political Liberalism-Conservatism and Left-Right Orientation in a Finnish Representative Sample. Social Psychology, 48(4), 246-251. doi:10.1027/1864-9335/ a000297

Koleva, S. P., Graham, J., Iyer, R., Ditto, P. H., \& Haidt, J. (2012). Tracing the threads: How five moral concerns (especially Purity) help explain culture war attitudes. Journal of Research in Personality, 46(2), 184-194. doi:http://dx.doi.org/10.1016/ j.jrp.2012.01.006

Kraft, P. W. (2018). Measuring Morality in Political Attitude Expression. Journal of Politics, 80(3), 1028-1033. doi:10.1086/696862

Malka, A., Osborne, D., Soto, C. J., Greaves, L. M., Sibley, C. G., \& Lelkes, Y. (2016). Binding Moral Foundations and the Narrowing of Ideological Conflict to the Traditional Morality Domain. Personality and Social Psychology Bulletin, 42(9), 1243-1257. doi:10.1177/0146167216653936

Metayer, S., \& Pahlavan, F. (2014). Validation of the Moral Foundations Questionnaire in French. Revue Internationale De Psychologie Sociale-International Review of Social Psychology, 27(2), 79-107. Retrieved from <Go to ISI>://WOS:000345482200004

Miles, M. R. (2016). Presidential Appeals to Moral Foundations: How Modern Presidents Persuade Cross-Ideologues. Policy Studies Journal, 44(4), 471-490. doi:10.1111/ psj.12151 
Milesi, P. (2017). Moral Foundations and Voting Intention in Italy. Europes Journal of Psychology, 13(4), 667-687. doi:10.5964/ejop.v13i4.1391

Milesi, P., \& Alberici, A. I. (2018). Pluralistic morality and collective action: The role of moral foundations. Group Processes \& Intergroup Relations, 21(2), 235-256. doi:10.1177/1368430216675707

Neiman, J. L., Gonzalez, F. J., Wilkinson, K., Smith, K. B., \& Hibbing, J. R. (2016). Speaking Different Languages or Reading from the Same Script? Word Usage of Democratic and Republican Politicians. Political Communication, 33(2), 212-240. doi:10.1080/10584609.2014.969465

Nilsson, A., \& Erlandsson, A. (2015). The Moral Foundations taxonomy: Structural validity and relation to political ideology in Sweden. Personality and Individual Differences, 76, 28-32. doi:10.1016/j.paid.2014.11.049

Petersen, M. B., Sznycer, D., Sell, A., Cosmides, L., \& Tooby, J. (2013). The Ancestral Logic of Politics. Psychological Science, 24(7), 1098-1103. doi:doi:10.1177/0956797612466415

Pietraszewski, D., Curry, O. S., Petersen, M. B., Cosmides, L., \& Tooby, J. (2015). Constituents of political cognition: Race, party politics, and the alliance detection system. Cognition, 140, 24-39. doi:http://doi.org/10.1016/j.cognition.2015.03.007

Rai, T. S., \& Fiske, A. P. (2011). Moral psychology is relationship regulation: Moral motives for unity, hierarchy, equality, and proportionality. Psychological Review, 118(1), 57-75. doi:10.1037/a0021867

Rempala, D. M., Okdie, B. M., \& Garvey, K. J. (2016). Articulating ideology: How liberals and conservatives justify political affiliations using morality-based explanations. Motivation and Emotion, 40(5), 703-719. doi:10.1007/s11031-016-9563-9

Riker, W. H. (1962). The Theory of Political Coalitions. New Haven and London: Yale University Press.

Schwartz, S. H. (1992). Universals in the content and structure of values: Theory and empirical tests in 20 countries. In M. Zanna (Ed.), Advances in experimental social psychology (Vol. 25, pp. 1-65). New York: Academic Press.

Sterelny, K., \& Fraser, B. (2016). Evolution and Moral Realism. British Journal for the Philosophy of Science, 68(4), 981-1006. Retrieved from https://academic.oup.com/ bjps/article-abstract/doi/10.1093/bjps/axv060/2669734/Evolution-and-Moral-Realism

Sterling, J., \& Jost, J. T. (2018). Moral discourse in the Twitterverse: Effects of ideology and political sophistication on language use among US citizens and members of Congress. Journal of Language and Politics, 17(2), 195-221. doi:10.1075/ jlp.17034.ste

Sychev, O. A., Belousov, K. I., \& Protasova, I. N. (2019). Values and Moral Foundations as a Basis for the Socio-Political Views of Youth. Sibirskiy Psikhologicheskiy ZhurnalSiberian Journal of Psychology(73), 60-77. doi:10.17223/17267080/73/4

Tomasello, M., \& Vaish, A. (2013). Origins of Human Cooperation and Morality. Annual Review of Psychology, 64(1), 231-255. doi:10.1146/annurev-psych-113011-143812

Voelkel, J. G., \& Brandt, M. J. (2019). The Effect of Ideological Identification on the Endorsement of Moral Values Depends on the Target Group. Personality and Social Psychology Bulletin, 45(6), 851-863. doi:10.1177/0146167218798822

Voelkel, J. G., \& Willer, R. (2019). Resolving the Progressive Paradox: Conservative Value Framing of Progressive Economic Policies Increases Candidate Support. SSRN. Retrieved from http://dx.doi.org/10.2139/ssrn.3385818

Weber, C. R., \& Federico, C. M. (2013). Moral Foundations and Heterogeneity in Ideological Preferences. Political Psychology, 34(1), 107-126. doi:10.1111/ j.1467-9221.2012.00922.x 
Weeden, J., \& Kurzban, R. (2015). The Hidden Agenda of the Political Mind: How SelfInterest Shapes Our Opinions and Why We Won't Admit It: Princeton University Press.

Weinschenk, A. C., \& Dawes, C. T. (2019). Moral Foundations, System Justification, and Support for Trump in the 2016 Presidential Election. Forum-a Journal of Applied Research in Contemporary Politics, 17(2), 195-208. doi:10.1515/for-2019-0012 Yalcindag, B., Ozkan, T., Cesur, S., Yilmaz, O., Tepe, B., Piyale, Z. E., . . Sunar, D. (2019). An Investigation of Moral Foundations Theory in Turkey Using Different Measures. Current Psychology, 38(2), 440-457. doi:10.1007/s12144-017-9618-4

Yilmaz, O., \& Saribay, S. A. (2019). Moral foundations explain unique variance in political ideology beyond resistance to change and opposition to equality. Group Processes \& Intergroup Relations, 22(8), 1124-1138. doi:10.1177/1368430218781012

Yilmaz, O., Saribay, S. A., Bahcekapili, H. G., \& Harma, M. (2016). Political orientations, ideological self-categorizations, party preferences, and moral foundations of young Turkish voters. Turkish Studies, 17(4), 544-566.

doi:10.1080/14683849.2016.1221312 